\title{
PENGARUH FAKTOR-FAKTOR INDIVIDUAL TERHADAP NIAT MELAKUKAN WHISTLE-BLOWING INTERNAL DAN EKSTERNAL PADA AKUNTAN DI BATAM (STUDI KASUS POLITEKNIK NEGERI BATAM)
}

\author{
Mega Mayasari ${ }^{1}$, Adi Irawan Setiyanto ${ }^{2}$, Rusda Irawati ${ }^{3}$ \\ ${ }^{1,2}$ Prodi Akuntansi/Manajemen Bisnis/Politeknik Negeri Batam, Indonesia \\ ${ }^{3}$ Prodi Administrasi Bisnis/Manajemen Bisnis/Politeknik Negeri Batam, Indonesia \\ Email: 'mega@polibatam.ac.id \\ Email: ${ }^{2}$ adiirawan@polibatam.ac.id \\ Email: ${ }^{3 i r a @ p o l i b a t a m . a c . i d ~}$
}

\begin{abstract}
ABSTRAK
Penelitian ini bertujuan untuk menguji persepsi karyawan Bagian Akuntansi di Batam terkait dengan pengaruh faktor individu terhadap niat melakukan internal dan eksternal whistle-blowing. Niat adalah keinginan seseorang untuk berperilaku. Hasil penelitian ini diharapkan dapat menambah pemahaman terkait dengan persepsi karyawan akuntansi terhadap intensi internal whistle-blowing dan external whistle-blowing. Tim peneliti juga berharap bahwa hasil penelitian ini dapat menjadi masukan bagi perusahaan di Batam, untuk merancang whistle-blowing dan melaporkan tindakan tidak etis di tempat kerja, sehingga dapat mendeteksi penipuan dan akhirnya tata kelola perusahaan yang baik dapat dibuat. Metode yang digunakan untuk memperoleh data penelitian adalah melalui penyebaran kuesioner kepada karyawan Program Studi Akuntansi Mahasiswa Politeknik Negeri Batam yang bekerja sebagai akuntan. Kuesioner yang dikumpulkan dianalisis menggunakan PLS-SEM. Hasil penelitian ini menunjukkan bahwa ada pengaruh perilaku whistle-blowing terhadap niat untuk melakukan internal whistle-blowing, ada pengaruh norma subyektif terhadap niat untuk melakukan eksternal whistle-blowing, ada pengaruh perilaku persepsi terhadap niat melakukan internal whistle-blowing. Di sisi lain, tidak ada pengaruh sikap terhadap whistle-blowing pada niat untuk eksternal whistle-blowing, tidak ada efek subyektif pada niat untuk melakukan internal whistle-blowing, tidak ada pengaruh kontrol perilaku perseptual pada niat untuk whistle-blowing eksternal.
\end{abstract}

Kata kunci: niat internal dan eksternal whistle-blowing, teori perilaku terencana.

\section{PENDAHULUAN}

Berdasarkan hasil survey di tahun 2015 Indonesia berada pada urutan 88 dari 167 negara terkait dengan tindakan korupsi pada sektor publik (www.transparency. org). Korupsi tidak hanya ditemukan pada organisasi sektor publik, pada organisasi swasta juga pernah ditemukan terjadinya tindakan kecurangan atau tindakan tidak etis. Seperti kasus korupsi yang terjadi pada PT Cevron Indonesia (CPI) yang dilakukan oleh empat karyawan perusahaan tersebut (sp.beritasatu.com). Hampir 40 persen dari kasus yang ditangani KPK itu melibatkan pihak swasta (Bambang dalam Irwan (2014). Pada tahun 2016 terjadi kasus kecurangan di PT EMR Indonesia (Batam), berupa penggelapan dana penjualan besi scrab sebesar tiga puluh enam miliar rupiah, terdeteksinya kecurangan tersebut karena ketidak seimbangan laporan keuangan perusahaan (Haluankepri. com). Melihat semakin maraknya tindakan kecurangan, membuat melaporkan tindakan tidak etis itu menjadi sesuatu yang penting.
Sebutan Batam sebagai kota industri, tidak lepas dari banyaknya perusahaan yang berdiri disana. Hal itu menyebabkan dibutuhkannya banyak tenaga kerja. Khususnya tenaga kerja Bagian Akuntansi untuk mengelola keuangan perusahaan. Karyawan yang bekerja pada Bagian Akuntansi perusahaan sudah tentu tahu dengan pasti bagaimana perusahaan itu berjalan. Karena bagian akuntansilah yang melakukan identifikasi bukti transaksi, penjurnalan sampai dengan proses penyusunan laporan keuangan. Alleyne et. al (2013) menyatakan bahwa karyawan bagian akuntansi peduli dengan kode etik perusahaannya. Sehingga lebih memungkinkan untuk memberikan pengaduan terkait dengan tindakan tidak etis. Penelitian ini menggunakan sampel penelitian karyawan akuntansi pada perusahaan di Batam.

David (2011) menjelaskan bahwa untuk menyelaraskan antara keputusan strategis dengan etika salah satunya adalah dengan mendorong whistle-blowing. Salah satu cara yang dilakukan 
untuk memerangi korupsi adalah dengan sistem whistle-blowing. Pendapat ini didukung oleh Alleyne et.al (2013) yang mengatakan bahwa alasan penting yang digunakan oleh manajemen untuk menerapkan prosedur terkait dengan whistleblowing adalah karena whistle-blowing dapat digunakan sebagai strategi untuk mempertahankan dan meningkatkan kualitas sebelum suatu masalah bertambah rumit. Whistle-blowing adalah kebijakan yang membutuhkan karyawan untuk melaporkan berbagai pelanggaran yang mereka temukan di dalam perusahaan (David, 2011). Mahkamah Agung melalui Surat Edaran Mahkamah RI Nomor 4 Tahun 2011 menerjemahkan whistle blower sebagai pelapor tindak pidana yang mengetahui dan melaporkan tindak pidana tertentu dan bukan bagian dari pelaku kejahatan yang dilaporkannya(wbs.menpan.go.id/) .

Penelitian yang dilakukan oleh Alleyne et. al (2013) menyatakan persepsi akuntan, whistleblowing bukanlah tindakan yang salah namun mereka menolak untuk mengungkapkannya. Banyak faktor yang menyebabkan seseorang tidak ingin melakukan whistle blowing, atau menolak untuk menjadi whistle-blower. Salah alasannya adalah karena takut terhadap pembalasan yang akan diterima dari tindakan pengungkapan tersebut. Bentuk pembalasan dapat berupa pemindahan ke bagian lain, pengurangan jam kerja, pemotongan gaji bahkan sampai kepada tindakan pemecatan.

Whistle-blower harus dilindungi karena pengungkapan yang dilakukannya untuk kepentingan umum dan untuk memerangi korupsi dan malpraktek yang terjadi (www.transparency.org). Alleyne et. al (2013) menyatakan bahwa untuk mendorong whistle-blowing suatu organisasi harus bisa mengimplementasikan program dan kebijakan yang terkait dengan perlindungan whistleblowers dari segala bentuk pembalasan seperti gangguan, hukuman dan bentuk pembalasan lainnya. Penelitian terkait dengan whistle-blowing pernah diteliti di luar negeri oleh Alleyne et.al (2013) tentang faktor-faktor yang diprediksi dapat mempengaruhi niat untuk melakukan whistle-blowing internal dan whistle-blowing eksternal. Hasil dari penelitian tersebut menyebutkan bahwa komitmen organisasi dan etika perusahaan secara signifikan mempengaruhi niat akuntan untuk melakukan tindakan whistle-blowing. Karyawan bagian akuntansi cendrung melakukan whistle- blowing internal jika tingkat komitmen terhadap organisasinya dan etika perusahaan memiliki tingkat yang lebih tinggi, dan sebaliknya akan melakukan whistle-blowing eksternal jika komitmen organisasi dan etika perusahaannya rendah. Diindonesia penelitian terkait dengan whistle-blowing pernah diteliti oleh Winardi (2013). Penelitian tersebut menguji faktor situasional dan faktor individual yang mempengaruhi niat pegawai negeri sipil untuk melakukan whistle-blowing. Hasil penelitian tersebut menunjukkan bahwa variabel yang mempengaruhi niat pegawai negeri sipil diIndonesia melakukan whistle-blowing adalah sikap terhadap whistle blowing (attitude towards whistle-blowing), norma subjektif (subjective norm), pengendalian perilaku persepsian (perceived behavioural control), seriouness of wrongdoing, status of wrongdoer. keseriusan kesalahan (seriouness of wrongdoing), status pembuat kesalahan (status of wrongdoer).

Perbedaan penelitian ini dengan penelitian terdahulu, ide penelitian berasal dari dua buah penelitian, faktor individual berasal dari Winardi (2013), sedangkan niat untuk melakukan whistleblowing internal dan niat untuk melakukan whistleblowing eksternal berasal dari Alleyne et.al (2013). Perbedaan berikutnya terletak pada sampel dan metode penelitian yang digunakan. Penelitian terdahulu menggunakan sampel pegawai negeri sipil dan akuntan di Barbados, penelitian ini menggunakan karyawan Bagian Akuntansi yang terdaftar sebagai mahasiswa kelas karyawan Politeknik Negeri Batam.

Berdasarkan uraian pada bagian latar belakang, maka tim peneliti tertarik untuk meneliti Bagaimana pengaruh faktor individual terhadap niat melakukan whistle-blowing internal dan eksternal. Tujuan dari penelitian ini adalah secara umum adalah untuk menguji pengaruh faktor individual terhadap niat melakukan whistle-blowing internal dan eksternal. Niat merupakan alasan penting terjadinya suatu perilaku. Manfaat yang diharapkan tim peneliti dari penelitian ini adalah dapat menambah pemahaman literatur yang berhubungan dengan Whistle-Blowing. Khususnya faktor individual yang mempengaruhi niat karyawan Bagian Akuntansi untuk melakukan Whistle-Blowing.

\section{METODE PENELITIAN}

Teori yang digunakan dalam penelitian ini adalah TPB (Theory of Planned Behaviour), 
TPB merupakan teori yang diusulkan oleh Ajzen. Menurut Hartono (2008) TPB menunjukkan bahwa tindakan manusia ditunjukkan oleh tiga macam kepercayaan-kepercayaan. Kepercayaan perilaku yaitu kepercayaan tentang kemungkinan terjadinya perilaku. Kepercayaan normatif yaitu kepercayaankepercayaan normatif tentang kepercayaan ekspektasi-ekspektasi normatif dari orang-orang lain dan motivasi untuk menyetujui ekspektasiekspektasi tersebut. Kepercayaan-kepercayaan kontrol kepercayaan tentang keberadaan faktor-faktor yang akan memfasilitasi atau merintangi kinerja dari perilaku dan kekuatan persepsian dari faktorfaktor tersebut. Semakin kuat niat maka semakin berhasil suatu perilaku. TPB mengembangkan TRA dengan menambahkan sebuah konstruk kontrol perilaku persepsian yang akan dipersepsikan akan mempengaruhi niat dan perilaku (Hartono, 2008).

Hipotesis penelitian yang diajukan:

Faktor individual

Sikap terhadap whistle-blowing (Attitude toward whistle-blowing)

H1a: Sikap terhadap whistle-blowing, berpengaruh terhadap niat untuk melakukan whistle-blowing internal

H1b: Sikap terhadap whistle-blowing, berpengaruh terhadap niat untuk melakukan whistle-blowing eksternal

\section{Norma subjektif (Subjective norm)}

H2a: Norma subjektif berpengaruh terhadap niat untuk melakukan whistle-blowing internal

H2b: Norma subjektif berpengaruh terhadap niat untuk melakukan whistle-blowing eksternal
Kontrol perilaku persepsian (Perceived Behavioural control)

H3a: Kontrol perilaku persepsian berpengaruh terhadap niat untuk melakukan whistleblowing internal

H3b: Kontrol perilaku persepsian berpengaruh terhadap niat untuk melakukan whistleblowing eksternal

Berdasarkan hipotesis penelitian, gambar 1 adalah model penelitian ini.

Data dalam penelitian ini menggunakan data primer. Data diperoleh melalui penyebaran kuesioner secara langsung kepada objek penelitian yaitu, mahasiswa kelas karyawan Politeknik Negeri Batam yang bekerja di Bagian Akuntansi pada perusahaan di Batam. Populasi penelitian ini adalah seluruh mahasiswa kelas karyawan program studi Akuntansi dan Akuntansi Manajerial Politeknik Negeri Batam. Sampel penelitian adalah mahasiswa kelas karyawan program studi Akuntansi dan Akuntansi Manajerial Politeknik Negeri Batam yang bekerja pada Bagian Akuntansi. Sampel penelitian diambil berdasarkan metode purposive sampling dengan kriteria mahasiswa kelas karyawan program studi Akuntansi dan Akuntansi Manajerial Politeknik Negeri Batam yang bekerja pada Bagian Akuntansi di Batam. Terdapat beberapa variabel yang diukur di dalam penelitian ini. Secara garis besar terdapat dua kelompok, yaitu variabel dependen dan variabel independen. Deskripsi variabel yang akan diukur dapat ditunjukkan pada tabel 1 .

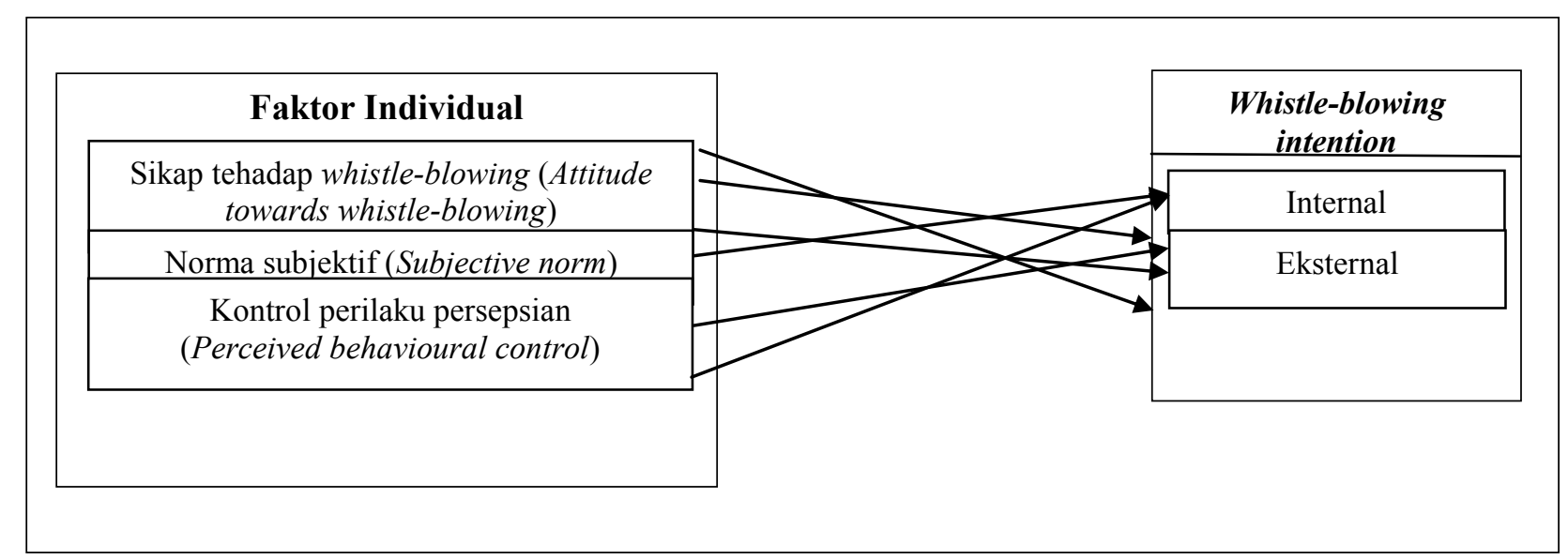

Gambar 1. Model Penelitian 
Tabel 1. Variabel Penelitian

\begin{tabular}{|c|c|c|}
\hline Dependen Variabel: & Definisi dan Pengukuran & $\begin{array}{c}\text { Sumber } \\
\text { (adaptasi } \\
\text { kuesioner) } \\
\end{array}$ \\
\hline $\begin{array}{l}\text { Niat melakukan whistle-blowing } \\
\text { (internal dan eksternal) }\end{array}$ & $\begin{array}{l}\text { Niat melakukan whistle-blowing di dalam penelitian ini mengacu } \\
\text { kepada niat untuk melakukan whisle-blowing internal dan eksternal } \\
\text { (Alleyne et. al, 2013). Variabel niat untuk melakukan whisle- } \\
\text { blowing internal diukur dengan menggunakan } 6 \text { item pertanyaan, } \\
\text { teknik skala yang digunakan adalah } 5 \text { poin skala likert angka } 1 \\
\text { menunjukkan sangat tidak setuju sampai } 5 \text { menunjukkan sangat } \\
\text { setuju. } \\
\text { Sedangkan niat untuk melakukan whisle-blowing eksternal diukur } \\
\text { menggunakan single pertanyaan, teknik skala yang digunakan } \\
\text { adalah } 5 \text { poin skala likert, angka } 1 \text { menunjukkan sangat tidak setuju, } \\
\text { sedangkan angka } 5 \text { menunjukkan sangat setuju. }\end{array}$ & $\begin{array}{l}\text { (Alleyne et. al, } \\
\text { 2013) }\end{array}$ \\
\hline \multicolumn{3}{|c|}{$\begin{array}{l}\text { Independen Variabel: } \\
\text { Faktor Individual }\end{array}$} \\
\hline $\begin{array}{l}\text { Sikap tehadap whistle-blowing } \\
\text { (Attitude towards whistle- } \\
\text { blowing) }\end{array}$ & $\begin{array}{l}\text { Mengacu pada definisi Ajzen (2005) dalam winardi (2013) yang } \\
\text { menyatakan bahwa Semakin menguntungkan sikap terhadap } \\
\text { perilaku berkemungkinan lebih besar orang akan menjadikan niat } \\
\text { menjadi perilaku. Diukur dengan menggunakan } 10 \text { item pertanyaan, } \\
\text { teknik skala yang digunakan adalah } 5 \text { poin skala likert angka } 1 \\
\text { menunjukkan sangat tidak setuju sampai } 5 \text { menunjukkan sangat } \\
\text { setuju. }\end{array}$ & $\begin{array}{l}\text { Park \& } \\
\text { Blenkinsopp } \\
\text { (2009) yang } \\
\text { telah diadaptasi } \\
\text { oleh Winardi } \\
(2013)\end{array}$ \\
\hline $\begin{array}{l}\text { Norma subjektif (Subjective } \\
\text { norm) }\end{array}$ & $\begin{array}{l}\text { mengacu pada definisi Ajzen (2005) dalam Winardi (2013), yang } \\
\text { menyatakan persepsi sesorang tentang penilaian dari referensi } \\
\text { yang bisa diakses (contohnya keluarga, teman, bawahan dan } \\
\text { masyarakat) mengenai apakah ya, atau tidak orang itu harus } \\
\text { melakukan suatu perilaku. Diukur dengan menggunakan } 10 \text { item } \\
\text { pertanyaan. teknik skala yang digunakan adalah } 5 \text { poin skala likert } \\
\text { angka } 1 \text { menunjukkan sangat tidak setuju sampai } 5 \text { menunjukkan } \\
\text { sangat setuju. }\end{array}$ & $\begin{array}{l}\text { Park \& } \\
\text { Blenkinsopp } \\
\text { (2009) yang } \\
\text { telah diadaptasi } \\
\text { oleh Winardi } \\
\text { (2013) }\end{array}$ \\
\hline $\begin{array}{l}\text { Kontrol perilaku persepsian } \\
\text { (Perceived behavioural } \\
\text { control) }\end{array}$ & $\begin{array}{l}\text { mengacu pada definisi Alleyne, Hudaib \& Pike (2013) dalam } \\
\text { Winardi (2013) menyatakan bahwa persepsi di atas level kesulitan } \\
\text { melakukan sebuah perilaku tertentu. Diukur dengan menggunakan } \\
10 \text { item pertanyaan. teknik skala yang digunakan adalah } 5 \text { poin } \\
\text { skala likert angka } 1 \text { menunjukkan sangat tidak setuju sampai } 5 \\
\text { menunjukkan sangat setuju. }\end{array}$ & $\begin{array}{l}\text { Park \& } \\
\text { Blenkinsopp } \\
\text { (2009) yang } \\
\text { telah diadaptasi } \\
\text { oleh Winardi } \\
(2013)\end{array}$ \\
\hline
\end{tabular}

\section{Metode Analisis Data}

Data mentah yang berasal dari kuesioner ditabulasikan dan kemudian diolah menggunakan software pengolahan data Smart-PLS versi 3.

\section{HASIL DAN PEMBAHASAN}

\section{Pengujian Model Struktural}

Output model struktural penelitian dapat ditunjukkan pada gambar 2 .

\section{KESIMPULAN}

Sikap terhadap whistle-blowing (Attitude toward whistle-blowing)

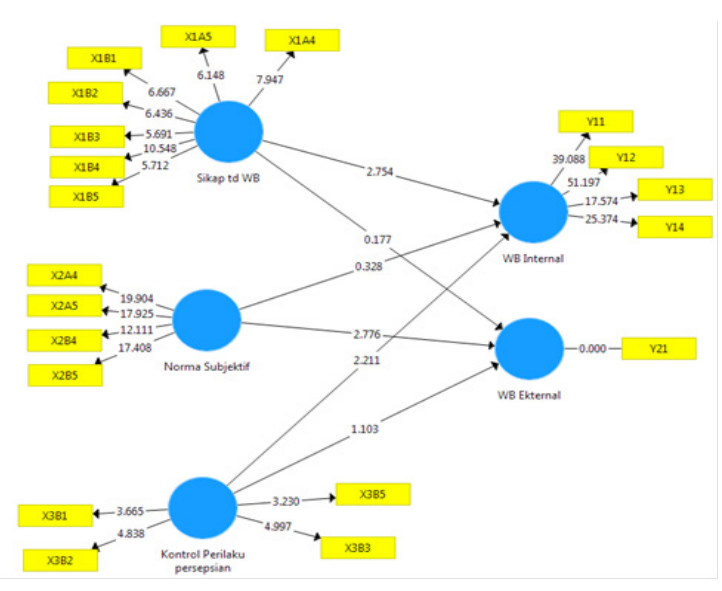

Gambar 2. Tampilan output model struktural 
Tabel 2. ringkasan hasil uji hipotesis

\begin{tabular}{lcl}
\hline Hipotesis & T statistic & Kesimpulan \\
\hline $\begin{array}{l}\text { H1a: sikap terhadap whistle-blowing, berpengaruh terhadap niat untuk melakukan whistle- } \\
\text { blowing internal }\end{array}$ & 2,754 & Terdukung \\
$\begin{array}{l}\text { H1b: sikap terhadap whistle-blowing, berpengaruh terhadap niat untuk melakukan whistle- } \\
\text { blowing eksternal }\end{array}$ & 0,177 & $\begin{array}{l}\text { Tidak } \\
\text { Terdukung }\end{array}$ \\
H2a: norma subjektif berpengaruh terhadap niat untuk melakukan whistle-blowing internal & 0,328 & $\begin{array}{l}\text { Tidak } \\
\text { Terdukung }\end{array}$ \\
& & Terdukung \\
H2b: norma subjektif berpengaruh terhadap niat untuk melakukan whistle-blowing eksternal & 2,776 & $\begin{array}{l}\text { Terdukung } \\
\text { H3a: kontrol perilaku persepsian berpengaruh terhadap niat untuk melakukan whistle- } \\
\text { blowing internal }\end{array}$ \\
$\begin{array}{l}\text { H3b: kontrol perilaku persepsian berpengaruh terhadap niat untuk melakukan whistle- } \\
\text { blowing eksternal }\end{array}$ & 1,103 & $\begin{array}{l}\text { Tidak } \\
\text { Terdukung }\end{array}$ \\
\hline
\end{tabular}

\section{a. Pengaruh Sikap terhadap whistle-blowing terhadap niat untuk melakukan whistle- blowing internal}

Berdasarkan hasil pengujian hipotesis, hipotesis 1a terdukung artinya terdapat pengaruh sikap terhadap whistle-blowing terhadap niat untuk melakukan whistle-blowing internal. Temuan ini sesuai dengan Theory of Planned Behaviour. Jika Akuntan di Batam menganggap bahwa dengan melakukan whistle-blowing internal/ melaporkan tindakan tidak etis melalui saluran internal seperti supervisor atau atasan langsung itu akan memberikan dampak yang positif maka niat Akuntan di Batam untuk melakukan whistle-blowing lebih besar. Temuan ini konsisten dengan Winardi (2013) yang menyatakan bahwa sikap terhadap whistle-blowing berpengaruh positif terhadap niat untuk melakukan whistle-blowing.

\section{b. Pengaruh Sikap terhadap whistle-blowing terhadap niat untuk melakukan whistle- blowing eksternal}

Berdasarkan hasil pengujian hipotesis, hipotesis $1 \mathrm{~b}$ tidak terdukung artinya tidak terdapat pengaruh sikap terhadap whistle-blowing terhadap niat untuk melakukan whistle-blowing eksternal. Responden dari penelitian ini rata-rata adalah akuntan yang berusia di bawah 25 tahun yang menganggap bahwa melakukan whistle-blowing eksternal akan membuat citranya buruk dan masih sedikit pengalamannya di dalam bekerja sehingga mereka bersikap lebih berhati-hati untuk mengungkapkan tindakan tidak etis kepada orang di luar perusahaan dapat menyebabkan ia kehilangan pekerjaannya.

\section{Norma subjektif (Subjective norm)}

a. Pengaruh Norma subjektif terhadap niat untuk melakukan whistle-blowing internal

Berdasarkan hasil pengujian hipotesis, hipotesis2a tidak terdukung artinya tidak terdapat pengaruh norma subjektif terhadap terhadap niat untuk melakukan whistle-blowing internal.

\section{b. Pengaruh Norma subjektif terhadap niat untuk melakukan whistle-blowing eksternal}

Berdasarkan hasil pengujian hipotesis, hipotesis $2 b$ terdukung artinya terdapat pengaruh norma subjektif terhadap niat untuk melakukan whistle-blowing eksternal. Jika pihak-pihak terkait seperti keluarga, orang tua, atasan menganggap bahwa whistle-blowing eksternal/melaporkan tindakan tidak etis kepada saluran di luar organisasi adalah suatu tindakan yang baik untuk dilakukan, maka akuntan akan melakukan tindakan tersebut. Hasil ini konsisten dengan Winardi (2013) yang menyatakan bahwa niat untuk melakukan whistle-blowing meningkat jika pegawai memiliki norma subjektif yang lebih besar.

\section{Kontrol perilaku persepsian (Perceived Behavioural control)}

\section{a. Pengaruh Kontrol perilaku persepsian terhadap niat untuk melakukan whistle- blowing internal}

Berdasarkan hasil pengujian hipotesis, hipotesis3a terdukung artinya terdapat pengaruh kontrol perilaku persepsian terhadap niat untuk melakukan whistle-blowing internal. Hasil penelitian ini konsisten dengan penelitian Winardi (2013) pegawai yang memiliki kontrol perilaku yang 
lebih tinggi lebih cenderung bertindak sebagai whistleblower.

\section{b. Pengaruh Kontrol perilaku persepsian berpengaruh terhadap niat untuk melakukan whistle-blowing eksternal}

Berdasarkan hasil pengujian hipotesis, hipotesis $3 \mathrm{~b}$ tidak terdukung artinya tidak terdapat pengaruh kontrol perilaku persepsian terhadap niat untuk melakukan whistle-blowing eksternal.

\section{UCAPAN TERIMA KASIH}

Ucapan terimakasih kami sampaikan atas partisipasi dan bantuanya kepada seluruh mahasiswa yang terpilih menjadi sampel. Manajemen Politeknik Negeri Batam yang telah mendukun penelitian ini. Kementrian Ristek Dikti yang telah mendanai penelian ini.

\section{DAFTAR PUSTAKA}

Alleyne, P., Marshall. D.W., Arthur, R. (2013). Exploring Factors Influencing Whistle-Blowing Intentions among Accountants in Barbados. Journal of Eastern Caribbean Studies. Vol.38, No.1 dan 2., March/June, pp.35-62.

David, Fred.R. (2011). Strategic Management (Concepts and Cases) thirteenth edition. Prentice Hall: United States of America.

Gudono dan Latan, H. (2013). Structural Equation Modeling. Yogyakarta: BPFE Yogyakarta.

Hartono, J. (2008). Sistem Informasi Keperilakuan Edisi Revisi. Yogyakarta: Andipublisher.

Hartono, J. (2011). Konsep dan Aplikasi Structural Equation Modeling Berbasis Varian dalam Penelitian Bisnis. Yogyakarta: UPP STIM YKPN.
Irawan, D. (2014). KPK: Selama Ini Hampir 40\% Pihak Swasta Terlibat Kasus Korupsi.dan. Gratifikasi.http://news.detik.com/read/201 4/11/26/130107/2759564/10/kpk-selamaini-hampir-40-pihak-swasta-terlibat-kasuskorupsi-dan-gratifikasi.

Johnson, W.B. (2012). How Do Police and Firefighters' Perceived Leadership Practices Relate to Organizational Commitment?. Nova Southeastern University: Dissertations Publishing.

Luthans, F. (2006). Perilaku organisasi (vol 10). Yogyakarta: Andi.

Sholihin, M \& Ratmono, D. Analisis SEM-PLS dengan WarpPLS 3.0 Untuk Hubungan Nonlinier Dalam Penelitian Sosial dan Bisnis. 1St Published.

Velasquez, Manuel G. (2006). Etika bisnis (Business Ethics, Concept and Case, $5^{\text {th }}$ edition, Edisi bahasa Indonesia. Yogyakarta: Andi.

Winardi, D.,R. (2013). The Influence of Individual and Situational Factors on Lower Level Civil Servants Whistle-Blowing Intention in Indonesia. Journal of Indonesian Economy and Business. Volume 28, Number 3, 2013, 361-367.

http://www.transparency.org, diakses April 2016. Enam Tersangka Kasus Korupsi Chevron Ditahan. (2013). Diakses Mei 2016. http:// sp.beritasatu.com/home/enam-tersangkakasus-korupsi-chevron-ditahan/25133.

http://Haluankepri.com/batam/85495-tengkatakanpt-emr-rugi-rp36-m.html. Diakses Juni 2016.

http://wbs.menpan.go.id. Diakses Juni 2016. 